\title{
An Analysis on Protecting Rights of Internet Finance Consumers in China
}

\author{
Li DAI
}

East University of Heilongjiang, Department of Economics and Trade, Harbin, China, 150066

dfxyjs@163.com

Keywords: Internet Finance, Finance Property, Consumer's Rights.

\begin{abstract}
This thesis aims at solving the problem about how to protect the rights of Internet Finance consumers. It adopted the methods of the document and qualitative analysis. The article made a deep analysis of the current financial consumption situation and the difficulties confronted by financial consumers' protection. The result shows that we can solve the problem by some effective measures, such as strengthening information disclosure and risk warning, enhancing security of internet system, establishing specific legislation and clarifying professional agencies, constructing internet financial regulation mechanism and so on.
\end{abstract}

\section{Introduction}

In recent years, financial industry has undergone profound changes based on the rapid development of modern information technology, especially the widespread use of search engines, cloud computing, mobile payments, social networks and big data. As a result, Internet Finance comes into being as a new financing model and rises rapidly. The emergence and development of Internet Finance brings some changes: on one hand, it is constantly stirring up the core parts of traditional financial sector and changing its business model; on the other hand, it not only provides Internet consumers more financial investment choices but also solves the problems such as the low rate of return on investment and illiquid assets etc. Therefore, it makes great sense to Internet consumers. It is that the rapid development of Internet Finance leads to the issue between its development and regulation. So that how to effectively protect the legitimate rights of financial consumers in Internet Financial Era has become an important task for financial regulatory agencies to study.

\section{Development of Current Internet Financial Consumption in China}

Due to the combination of Internet technology and financial services, business models have been changed; Internet Finance has been innovated; a new model for financial operation and product structure has been formed. The main models of Chinese Internet Finance include third-party payment, small loans for E-business networks, P2P network credit platform, Crowdfunding, Internet Financing and Insurance and other Internet financial serving platforms. It is important to say that these kinds of platforms actually help Internet financial consumers to enjoy incomparable services.

Innovative financial products have brought the rapid development of Internet finance consumption. Recent years in China, the scale of online shopping transactions continues to expand which leads to the sudden appearance of third-party payment platform, it is used to solve credit issues between both transaction parties. Third-party payment platform plays a role of intermediary financial guarantees in online shopping, thus to boost the development of online payments, Internet Financing and Insurance and other businesses. It also enriches the contents of products system of the Internet consumption. Since the third-party payment platform is continuously developing traditional financial core business, financial institutions are forced to adjust the model and idea of operation. Banks begin to employ the model which combines the financial services with e-commerce business, and focus on the development of new Internet services. Meanwhile the innovation of Internet Finance products has been made a big step. Balance pay turned out in June 2013, which was called "Internet financing artifact" due to the advantages including flexibility, convenience, high-yields and low barriers to financial constraints etc. We can say that it is Balance pay begins the new era of Internet financing. As another kind of model, P2P network credit 
platform can control the risk through measures like real estate mortgage loan, which makes loads for 40 million small and micro enterprises more realizable and increases their credibility. What's more, it brings vitality for illiquid real estate market, and solves the problems such as low rate of return and illiquid assets in past investment. P2P network credit platform provides financial consumers more choices and strongly promote the development of the Internet financial consumption.

The rapid development of Internet financial consumption brings more convenience, but also produces the challenges for financial regulation and protection of consumer rights. In the current Internet financial environment, consumers are in relatively weak positions, whose rights and interests are vulnerable to be infringed; and the virtual nature of the Internet makes this vulnerability hard to be used timely. Nowadays, it is particularly urgent to strengthen the protection measures of the legitimate rights of financial consumers.

\section{Analysis of Factors Leading to Financial Infringements}

\section{Asymmetry of Information}

Information asymmetry refers to the differences of relevant information possessed by transaction parties in current economic life, which contains differences of the amount of information and also the obtaining ways of information. In the transaction process, you will be in a dominant position if you grasp more information; otherwise, you will be in an inferior position if you have less information. According to economic theory, buying behaviors of financial consumers are performed after making a comprehensive analysis of all relevant information. In the Internet Finance environment, financial products are too professional; network transactions are too virtual; some agencies propaganda products with a misleading marketing method, so that consumers will pay much emphasis on income other than diluting risks. For lacking relative information about financial transactions, consumers will be in a disadvantaged position thus they cannot make a good understanding of the actual case of the products they have bought. This fact makes it impossible for consumers to enjoy the rights to know financial situation and fairly trade.

\section{Potential Danger of Internet}

Internet financial products and services are all operated in an electronic data oriented mode, so a variety of transactions are carried out on the basis of Internet. The openness of the Internet will increase the risks of trading behaviors. In the Internet Finance environment, all kinds of trade information needs to be transmitted via the Internet, so lack of technical means or the internal control mechanism will increase the risk of financial consumers' personal information being leaked or improperly used, and consumers are subject to different degrees of damage. As a result, legitimate rights financial consumers cannot be protected; the leakage of personal information can cause the insecurity of consumers' financial assets, even can make them confronting Internet frauds.

\section{Lack of Specific Legislation and Professional Agencies}

Firstly, there is no specific legislation for the financial consumer's protection in China. What we have now is Consumer Protection Act which only ordains protection against the rights of consumers for general consumption of goods and services. Although the revised Consumer Protection Act involves the words of financial consumers, it does not clear its real meaning and legal interests, thus many problems of Internet finance still cannot be solved.

Secondly, there are no professional agencies for the protection of the consumers' financial rights. It is difficult for existing business sectors and consumer associations to deal with financial consumer disputes for unknown powers and responsibilities and lack of expertise. This will cause the following situations: the main responsibility not clear; lack of appropriate authorities and human rights organizations, which make consumers impossible to protect their legitimate rights. 


\section{Lack of Regulation System}

As a financial innovation, Internet Finance is in a state of disordered development, and urgently needs to be regulated and guided. However, there is no an established and comprehensive Internet financial regulatory system in China. Firstly, Internet Finance markets have no rules for restricting joining. The current condition is that financial companies can engage in any financial activities with no restrictive requirements if they have business licenses and also recorded by relevant departments. This makes the entire Internet industry showing good-and-bad financial state, and hinders the establishment of an Internet financial market order. Secondly, Internet Finance markets are lacking of operational regulations. In terms of regulatory compliance, the regulation of Internet Finance enterprises has no laws to follow because of lacking of legal basis. Different from traditional financial institutions, Internet Finance enterprises have not so strict limitations in aspect of regulatory risk, so it is difficult to effectively protect the financial property safety of consumers. Thirdly, Internet Finance markets lack mechanisms for withdrawing out. Like other industries, Internet Finance enterprises must be in a survival of the fittest environment for better development. Nevertheless, there is no restriction which financial firms must follow when they decide to exit the Internet Finance markets, regardless of the financial consumers' protection. This factor makes the legitimate rights of financial consumers are easier to be violated.

\section{Lack of Financial Knowledge and Risk Awareness}

Internet Finance is still in primary stage in China. It is a common phenomenon that Internet Finance consumers are lacking the financial knowledge, the ability to identify risks and weak awareness. Coupling with misleading marketing propaganda from many Internet financial firms, consumers will pay much more attention on high-yields other than the potential risks when they are buying financial products. Under the condition of lacking financial knowledge and risk awareness, consumers' rights are easy to be infringed.

\section{Advice on Strengthening Protection against Financial Consumers}

\section{Strengthening Information Disclosure and Risk Warning}

It is an effective way to solve the problem of information asymmetry. The relevant institutions should establish Internet information disclosure and financial management practices as soon as possible, which stipulate that Internet finance operators must provide details of information disclosure and risk warning of related products and services; and guarantee all the information accurate. Based on this kind of information, financial consumers can make more rational choices, thus to realize their rights to know about products and trade fairly. The information provided by Internet finance operators should include not only general information like types of businesses, conditions of operations and developing strategies, but also key information like features of financial products or services, investment, risk and rates charged information. Internet finance operators should ensure that consumers can learn the relevant financial information and reduce the risk for consumers. Approaches for Internet financial information disclosure should be further improved at the same time, which should be expounded in understandable, clear and concise expressions and then passed to consumers for strengthening information disclosure and risk warning, and realize the Right to Know.

\section{Enhancing Security of Internet System}

In Internet finance environment, privacy of personal information and security of property network accounts is the core part of the Internet financial consumer protection. Internet financial enterprises should protect personal information and property security of consumers through measures like enhancing network security and strengthening internal controls.

Internet financial enterprises should strengthen their network security construction, increase the investment on information security technology research and development and promotion, set up security ranking standard, enhance system's protection capability, conduct information system audit, dynamically track the security ranks of Internet financial operators, release the tracking results in time, provide 
appropriate risk warning and fight against continuous risks.

Internet financial enterprises ought to focus on their own internal controls, establish a comprehensive system, strengthen the confidentiality of important information for customer identification, establish bank custody system for network accounts and publish the use of funds in real time. They should make the fund utilization in openness and transparency way, if so, the security of financial property information of consumers can be protected well.

\section{Establishing Specific Legislation and Clarifying Professional Agencies}

Related departments should quickly introduce a specific Financial Consumer Protection Act, which defines the meaning of financial consumers and their legitimate rights from a legal perspective, standardizes the behaviors of market players, and acts as the legal basis for the financial rights of consumers' protection. Furthermore, it should timely amend relevant laws and regulations, and improve credit system and other supporting information disclosure system. In current situation, it should establish special Provisional Regulations to solve the burning questions during the working process of protecting financial consumers' rights, and then make them as basic laws in suitable conditions. In addition, professional agencies should be set up to protect financial interests of consumers. This kind of agencies should provide specialized financial protection for consumers, thus to promote the healthy development of the Internet Finance.

\section{Constructing Internet Financial Regulation Mechanism}

Currently, we can construct financial regulation mechanism from aspects of joining, operating and exiting the Internet financial markets in China. Firstly, it should set up market joining rules which stipulate appropriate conditions and standards for units being in or going to be in Internet financial markets, only the one that meets the requirements can be given operating license of Internet financial services, others will not be allowed to run the Internet financial services. Secondly, it should introduce market operating rules, which standardize business practices of Internet financial institutions and perform compliance regulation and make appropriate rules to create fair competitive environment. What's more, these rules should also include specific standards for important business indicators, rank the creditability of Internet financial enterprises and provide reference information for financial consumers. Last, it should contain market exiting rules. If Internet financial enterprises exit market with lack of funds, consumers' rights will be infringed. In order to avoid that kind of infringement, each enterprise should pay a certain amount of money according to the stipulation, and this fund is hosted by a third party. When consumers suffer property damage due to bankruptcy, they can apply for compensation; thereby the legitimate rights of Internet financial consumers can be effectively and fully protected.

\section{Increasing Risk Awareness of Financial Consumers}

Effective improvement of financial literacy and risk awareness for consumers is the foundation to reduce consumption disputes and thus to protect their legitimate rights. From the consumer's point of view, Internet financial consumers should continue to learn financial knowledge and enhance their ability to identify potential risks of buying financial products, then to choose Internet financial products and activities correctly; they should also improve their risk prevention awareness and develop good habits of the Internet spending in order to protect their property and information from being damaged. From the perspective of financial institutions, they should actively fulfill their social responsibility, firmly establish a sense of safeguarding legitimate rights of financial consumers, and fully reflect the financial concepts and requirements of rights of consumers' protection in all stages of businesses. Financial institutions can help consumers improve their risk prevention awareness and contribute to rational consumptions through following methods like distributing leaflets, organizing financial literacy public lectures, posting shop notices and popularizing Internet knowledge and so on.

Not only should we protect legitimate rights of financial consumers from being infringed, but also need to coordinate the relationship between financial innovation and consumer rights protection. For one thing, it is necessary to encourage financial innovation, so that consumers can enjoy more and better financial value-added services. For another, industry regulation and self-regulation should be strengthened to 
identify and fight against financial risks. With the advancement of Internet technology and continuous application of financial innovation, the regulation of Internet finance should keep following up, only then can Internet finance industry be developed in a healthy and stable state.

\section{References:}

[1] Dai Li. A Study on Strategies for Protecting Rights of Insurance Consumers in China. Journal. Consumer Economics, 2012(4):44-47.

[2] Hu Guangzhi, Zhuoqiang. A Discussion on Consumers' Rights Protection in Internet Financial Innovation in China. Journal. Law Review, 2014(6):135-143.

[3] Liu Jianjun. Risks and Countermeasures for Protecting Rights of Online Finance Consumers. Journal. Productivity Research, 2013(12):27-30.

[4] Wu Xiaoguang, Chenjie. An Analysis of Protecting Rights of Consumers in Internet Financial Environment. Journal. Financial Perspectives Journal, 2011(3):55-58. 